\title{
PENTINGNYA PENERIMAAN DIRI BAGI REMAJA PANTI ASUHAN ISLAM
}

\section{Kuncoro Lestari Anugrahwati ${ }^{1}$ \& Anak Agung Ketut Sri Wiraswati}

\author{
Universitas Surabaya
}

\section{Keywords/Kata kunci \\ adolescents, meaning of life, orphanage, self- acceptance}

kebermaknaan hidup, panti asuhan, penerimaan diri, remaja

\begin{abstract}
ABSTRAK:
The adolescents in orphanage have different way of feeling loved by their parents' figure. This divergent with adolescents in general might raise various problems for developing their identities. They get the stigmas from society as "orphan", and it becomes hindrance in their development. Thus, to boost their own development, self-acceptance is one factor to be concerned. The purpose of this training is to help adolescents to achieve self-acceptance. This research is conducted with experimental method based on Bastaman's factor of self-acceptance. Participants were given training related to self-insight, meaning of life, changing attitude, selfcommitment, directed activities, and social support to increase the selfacceptance of adolescents in orphanage X. Conducted evaluations showed the significancy of 0,014 on t-test between pretest and post-test. This shows the impact of the training on adolescents in the orphanage to develop their self-acceptance for their well- being.
\end{abstract}

Tidak semua remaja memiliki keberuntungan dalam hal memperoleh dukungan sosial dan kasih sayang dari orangtuanya. Hal ini menimbulkan berbagai problematika bagi remaja dalam mengembangkan identitasnya. Label sebagai anak didik panti asuhan atau yatim piatu menjadi sumber stres bagi remaja, sebab menghasilkan berbagai kemungkinan pengalaman buruk pada anak didik panti asuhan di masa depan. Sasaran dari pelatihan ini adalah membantu remaja di panti asuhan agar mampu mencapai penerimaan diri. Penelitian ini dilakukan dengan metode eksperimen berdasarkan faktor penerimaan diri dari Bastaman. Partisipan diberikan pelatihan yang memuat selfinsight, meaning of life, changing attitude, self-commitment, directed activities, dan social support untuk meningkatkan penerimaan diri remaja panti asuhan. Perbandingan tes awal dan tes akhir menunjukkan adanya perbedaan penerimaan diri dengan nilai signifikansi 0.014 . Artinya, pelatihan ini dapat meningkatkan penerimaan diri pada remaja Panti Asuhan Islam.

\footnotetext{
${ }^{1}$ Korespondensi mengenai artikel ini dapat dilakukan melalui xiangx000@gmail.com 
Remaja merupakan fase usia yang penuh perjuangan. Pada masa ini remaja beralih untuk meninggalkan peran sebagai anak-anak menuju peran dan tanggung jawab sebagai orang dewasa (Newman \& Newman, 2012). Berbagai isu mulai bermunculan ketika seseorang menginjak usia remaja. Kenakalan remaja, penyalahgunaan obat-obatan, konsumsi rokok dan minuman beralkohol, hingga seks bebas dan penyakit menular seksual (Papalia et al., 2008).

Krisis perkembangan psikososial identity versus identity confussion menjadi isu yang dihadapi oleh remaja. Membangun identitas diri yang positif dan stabil menjadi tugas yang harus dipenuhi remaja agar dapat berhasil di jenjang usia perkembangan selanjutnya (Papalia et al., 2008).

Pada dasarnya perkembangan identitas remaja didukung oleh dukungan sosial yang diberikan oleh orangtua. Akan tetapi, tidak semua remaja memiliki keberuntungan yang serupa untuk memperoleh dukungan sosial dan kasih sayang dari orangtuanya. Sebagian remaja kurang memperoleh kasih sayang, kedekatan, dan perhatian dari orangtuanya sehingga dititipkan untuk dididik dan dibesarkan di panti asuhan dengan berbagai alasan. Remaja yang hidup di panti asuhan cenderung mengembangkan konsep diri yang negatif, rentan mengalami gejala depresi, PTSD, serta agresivitas yang tinggi (Hermenau et al., 2015). Bahkan, penerimaan diri, personal growth, psychological well-being remaja panti asuhan secara umum lebih rendah jika dibandingkan dengan remaja yang tidak tinggal di panti asuhan (Khan \& Jahan, 2015).

Label sebagai remaja di panti asuhan menjadi sumber stres bagi mereka, sebab menghasilkan berbagai kemung- kinan pengalaman buruk oleh remaja panti asuhan di masa depan seperti diskriminasi dan iri hati karena kurangnya kesempatan dan sumber daya yang mereka peroleh (Carpenter, 2014). Lingkungan cenderung memiliki persepsi negatif pada remaja panti asuhan seperti memiliki pengalaman hidup yang pahit dan buruk, adanya penolakan yang menyebabkan permasalahan psikologis yang dialami remaja panti asuhan (Hermenau et al., 2015). Pandangan lain juga menunjuk remaja panti asuhan rentan terlibat dalam perilaku negatif, memiliki rasa percaya diri yang rendah, rapuh dan rentan secara psikis (Hermenau et al., 2015). Stereotip dan peristiwa negatif yang pernah dilewati membuat remaja panti asuhan rentan memiliki penerimaan diri yang rendah, memandang diri dan peristiwa di sekitar secara negatif, mereka juga memiliki iri hati yang mewarnai perasaannya.

Penerimaan diri merupakan salah satu prediktor dari sebuah pribadi yang sehat dan matang (Hjelle \& Ziegler, 1981). Penerimaan diri menjadi krusial bagi remaja dalam upaya mencapai konsep diri yang positif. Penerimaan diri menjadi akar agar seseorang dapat menyesuaikan diri secara adekuat dengan lingkungan dan setiap pengalaman yang diperoleh, sehingga mencapai personal growth (A twate r, 1983) well-being dan aktualisasi diri (Feist \& Feist, 2009 ) Ketika individu mampu menerima diri secara utuh dengan kelemahan dan kelebihan yang dimiliki, maka antara ideal self dan real self tidak akan terpisah oleh jurang yang terlalu jauh (Feist \& Feist, 2009). Fakta di lapangan bahwa sebagian remaja panti asuhan belum mampu secara utuh menerima keadaan diri yang dititipkan di panti asuhan. Tidak jarang remaja merasa terbuang dari keluarga, atau sengaja dijauhkan dari orangtua masingmasing (Wiraswati, 2016). 
Panti Asuhan X memiliki total 34 remaja berjenis kelamin laki-laki. Masingmasing remaja masuk panti asuhan dengan latar belakang alasan yang berbeda. Sebagian remaja masih memiliki orangtua lengkap, namun karena keterbatasan finansial untuk menghidupi dan membiayai pendidikan anak, membuat orangtua mengambil keputusan untuk menitipkan anak di panti asuhan. Sebagian anak juga berstatus yatim. Keberadaan ibu yang bekerja sebagai tenaga kerja di luar negeri membuat anak tidak dapat bersama dengan ibunya. Adapula anak yang yatim, namun keberadaannya tidak dikehendaki oleh ibunya. Berbeda lagi dengan anak yang memiliki keluarga dan cukup mapan secara finansial, namun keberadaan anak tersebut tidak diinginkan oleh keluarganya.

Latar belakang penyebab dari keberadaan remaja di panti asuhan $\mathrm{X}$ sebagian besar karena orang tua tidak mampu membiayai sehingga harus menetipkan salah satu anaknya, ada juga yang dititipkan karena orang tua lelah untuk mengurus. Hal ini mengakibatkan penolakan dan tidak semuanya mampu menerima keadaan bahwa dirinya menjalani kehidupan di asrama panti asuhan dengan segala hak dan kewajiban panti. Penelitian yang dilakukan oleh Kuyumcu \& Rohner (2018) menyatakan bahwa penerimaan diri seseorang dipengaruhi oleh penerimaan orang tua, penelitian ini mendukung temuan peneliti melalui wawancara. Tidak semua remaja mampu memahami makna di balik pilihan orangtua masing-masing untuk menitipkan mereka di panti asuhan karena merasa ditolak terlebih dahulu. Remaja panti asuhan justru merasa diasingkan, bahkan merasa dibuang dari keluarganya ketika orangtua menitipkan mereka di panti asuhan.

Belum mampunya remaja menerima situasi dan kondisi mereka saat ini menimbulkan beberapa permasalahan, seperti kurang disiplin pada aturan, prestasi belajar yang rendah, ekspresi emosi yang kurang terkendali. Perilaku yang khas muncul dari remaja panti asuhan yaitu merasa iri hati pada anak yang tidak tinggal di panti asuhan karena jurang perbedaan yang cukup jauh secara materi dan nonmateri. Remaja juga merasa kurang percaya diri ketika bergaul dengan anak lain di luar Panti Asuhan X, dan kurang memiliki rasa tanggung jawab untuk melaksanakan kewajiban secara sukarela sebagai remaja panti asuhan.

Berdasarkan wawancara dengan pengelola panti, anak didik yang sudah berusia remaja sering kali masih perlu ditegur dan diingatkan oleh orangtua asuh untuk mengerjakan kewajiban seperti mandi, piket membersihkan asrama, dan mengerjakan tugas sekolah. Kurangnya penerimaan diri remaja atas kondisi saat ini memunculkan sense of belonging yang rendah pada fasilitas dan kehidupan di panti asuhan, sehingga berimbas pada kurangnya rasa tanggung jawab. Selain itu juga perilaku sebagian remaja menunjukkan kurangnya disiplin untuk menaati aturan yang ditetapkan panti asuhan, misalnya pulang tengah malam atau keluar di malam hari dengan cara melompati pintu pagar agar tidak diketahui orangtua asuh yang berjaga.

Berdasarkan hasil wawancara dan proses triangulasi data hasil wawancara bersama sampel pengurus yayasan, orangtua asuh (penanggungjawab asrama panti asuhan), dan anak didik panti asuhan, diperoleh beberapa kebutuhan yang akan menjadi sasaran pelatihan dan pengembangan. Kebutuhan yang akan menjadi sasaran meliputi: a) Anak masih belum mampu menerima keadaan diri, bahkan merasa iri; b) Anak didik cenderung memberontak, dan meluapkan emosi secara meledak-ledak; c) Kurang percaya diri; d) Mengalami kebingungan terhadap masa depan. 
Hasil wawancara menunjukan sebagian besar permasalahan yang dialami remaja panti asuhan bersumber dari kurangnya penerimaan diri terhadap kondisi kehidupan saat ini. Pelatihan ini disusun untuk memenuhi kebutuhan remaja didik panti asuhan yang berfokus pada meningkatkan penerimaan diri, sehingga semakin membuka peluang bagi remaja untuk mengembangkan berbagai aspek psikis positif lain. Pelatihan ini mengandung faktor-faktor yang mempengarui penerimaan diri milik B a staman ( $\left.\begin{array}{llll}2 & 0 & 0 & 7\end{array}\right)$ yaitu self-insight, meaning of life, changing attitude, self-commitment,directed activities, dan social support.

Gambar 1. Skema Teoritik

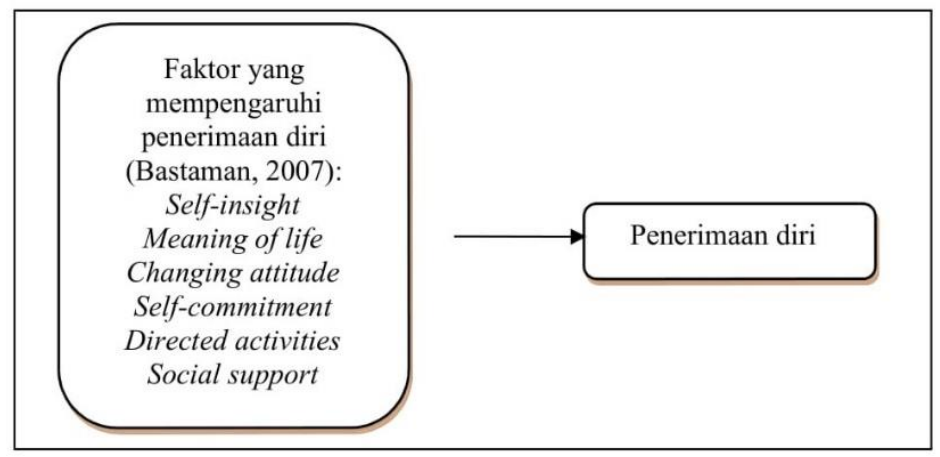

Pada penelitian ini juga dapat dilihat apakah faktor yang mempengaruhi penerimaan diri (Bastaman, 2007) dapat secara efektif meningkatkan penerimaan diri remaja panti asuhan X. Sasaran dari pelatihan dan pengembangan ini adalah membantu remaja agar mampu meningkatkan penerimaan diri. Peneliti menggunakan faktor-faktor yang mempengaruhi penerimaan diri ini untuk dijadikan training pelatihan.

\section{METODE PENELITIAN}

\section{Desain Penelitian}

Dalam penelitian ini peneliti menggunakan pendekatan kuantitatif dengan rancangan penelitian quasieksperimen. Tes awal akan dilakukan sebelum pemberian pelatihan dan tes akhir diberikan setelah keseluruhan proses pelatihan selesai dilaksanakan (one group prates-paskates design). Seluruh subjek dimasukkan ke dalam satu kelompok eksperimen, tanpa adanya kelompok kontrol (Mertens, 2014), hal ini dikarenakan minimnya subjek dan permintaan pihak panti untuk melatih seluruh anak remaja. Kelompok eksperimen ini akan diberikan pelatihan yang didasarkan pada faktor penerimaan diri dari Bastaman.

Pelatihan dilakukan sebanyak dua kali. Pelatihan pertama dan kedua memiliki jarak waktu satu minggu. Pelatihan hari pertama diberikan mulai pukul 8.00 hingga 15.00, sedangkan di hari ke dua dimulai pukul 08.30 hingga 15.30. Akan ada beberapa metode yang digunakan untuk menyampaikan materi dalam pelatihan ini, yaitu lecturing, diskusi panel (presentasi dan diskusi), audiovisual, games, mental imagery, serta writing task. Dalam penelitian ini dilakukan evaluasi yang melibatkan dua aspek yaitu pembelajaran (learning), dan perilaku (behavior). Evaluasi ini diperoleh melalui wawancara, observasi, dan pemberian skala penerimaan diri kepada partisipan pada awal dan akhir pelatihan. 


\section{Subjek Penelitian}

Pemilihan subjek dalam penelitian ini menggunakan metode purposive sampling. Subjek terdiri dari 14 remaja lakilaki panti asuhan Islam X Surabaya yang memiliki rentang usia 15-18 tahun dan bersedia mengikuti pelatihan dari awal hingga akhir dengan mengisi informed consent.

\section{Metode Pengumpulan Data}

Pada awalnya, untuk mengetahui kebutuhan penerimaan diri remaja Panti
Asuhan Islam X, dilakukan wawancara kepada tiga pihak, yaitu pengurus yayasan, orangtua asuh (penanggung jawab asrama), dan remaja panti. Observasi juga dilakukan peneliti untuk memperkaya data studi awal terhadap kondisi penerimaan diri remaja panti asuhan.

Selanjutnya, data kuantitatif dikumpulkan melalui pemberian skala penerimaan diri pada bagian awal dan akhir pelatihan. Tabel 1 berikut ini merupakan blueprint dari skala penerimaan diri.

Tabel 1. Blueprint skala penerimaan diri

\begin{tabular}{|c|c|c|c|c|}
\hline No & Aspek & Eayorable & Unfavorable & Total \\
\hline 1 & $\begin{array}{l}\text { Memiliki efikasi diri yang } \\
\text { tinggi. }\end{array}$ & 3, & $6,14,16$ & 4 \\
\hline 2 & $\begin{array}{l}\text { Menganggap diri berharga } \\
\text { sederaiat dengan orang lain. }\end{array}$ & $2,18,22$ & 8 & 4 \\
\hline 3 & Menjadi diri yang otentik. & 4,20 & 5,21 & 4 \\
\hline 4 & $\begin{array}{l}\text { Memiliki kepercayaan diri } \\
\text { yang baik. }\end{array}$ & 12,23 & 7,10 & 4 \\
\hline 5 & $\begin{array}{l}\text { Berani memikul tanggung } \\
\text { jawab pada perbuatan } \\
\text { pribadi. }\end{array}$ & 13 & 19 & 2 \\
\hline 6 & $\begin{array}{l}\text { Mampu menerima pujian dan } \\
\text { kritik secara objektif. }\end{array}$ & 11 & 17 & 2 \\
\hline 7 & $\begin{array}{l}\text { Menerima kekuatan dan } \\
\text { kelemahan diri. }\end{array}$ & 15 & 1,9 & 3 \\
\hline Total & & 11 & 12 & 23 \\
\hline
\end{tabular}

Koefisien korelasi aitem total dalam skala penerimaan diri bergerak antara 0.375-0.705 dengan jumlah aitem total 23 butir. Koefisien reliabilitas skala penerimaan diri dengan jumlah aitem total 23 butir adalah 0.889 .

\section{Prosedur Intervensi}

Materi dalam penelitian ini dikemas dalam beberapa metode. Mengacu pada metode yang diungkapkan oleh Yoder dalam (Moekijat, 1981), dipilih beberapa metode yang akan digunakan sebagai cara penyampaian materi dalam pelatihan. Adapun metode yang digunakan yaitu:

\section{Lecturing}

Metode ini digunakan untuk memberikan informasi, pengetahuan, dan pemahaman dari trainer kepada peserta. Informasi disampaikan secara lisan. Peserta dapat memperhatikan atau mencatat pokok materi yang penting.

2. Diskusi panel (presentasi dan diskusi)

Metode diskusi panel adalah suatu proses penglihatan dua atau lebih individu yang berinteraksi secara verbal dan saling bertatap muka dalam satu situasi yang sama. Tujuan metode 
ini untuk berbagi pendapat, bertukar informasi, dan memecahkan masalah.

3. Audiovisual

Metode audiovisual merupakan sarana yang menitikberatkan pada indera penglihatan dan pendengaran sebagai penangkap informasi Pembelajaran melalui metode audiovisual dapat digunakan untuk membantu dalam penyampaian informasi yang sulit dijelaskan dengan cara lisan. Keuntungan metode ini adalah dapat menampilkan konsep- konsep pembelajaran dalam bentuk konkrit dengan fakta-fakta yang dapat diamati.

\section{Games}

Metode bermain digunakan sebagai sarana untuk memunculkan pengalaman belajar secara langsung (learning by doing). Permainan membuat peserta dapat menyalurkan energi secara positif dan menumbuhkan karakteristik positif dalam diri peserta. Metode ini juga membuat peserta terhindar dari kebosanan akibat metode lain yang dilakukan dalam pelatihan (Bahari, 2013).

\section{Mental imagery}

Metode ini adalah suatu proses membayangkan suatu kejadian atau hasil yang belum di capai oleh peserta, mental imagery memerlukan proses kognisi dan stimulasi dari eksternal (oleh trainer). Metode ini berguna untuk meningkatkan kesadaran terhadap tantangan di masa depan yang berguna untuk menimbulkan persiapan dalam hidup.

6. Writing task

Metode menulis paper and pencil assignment utamanya digunakan dalam penugasan untuk mengungkap isi pikiran dan perasaan peserta, khususnya bagi peserta yang kurang mampu mengungkapkan pikiran dan perasaannya secara lisan. Melalui metode ini peserta juga menuliskan jawaban-jawaban yang bersumber dari pengetahuan yang dimiliki untuk menjawab suatu persoalan.

Pelatihan dilakukan selama 2 hari. Pelatihan ini ditujukan untuk remaja Panti Asuhan X yang kini duduk di kelas X-XII sebanyak 21 orang. Topik besar yang diusung oleh trainer adalah penerimaan diri (self-acceptance). Rancangan dan materi pelatihan mencakup aspek-aspek penerimaan diri, yakni:

\section{a. Sesi I:}

Peserta diajak untuk bermain games terkait sikap, dilanjutkan dengan review games dengan materi tersebut. Kemudian peserta diminta untuk menganalisis karakteristik tokoh film sesuai materi sebelumnya dan mempresentasikannya.

b. Sesi II:

Peserta diajak untuk mengenal dirinya melalui hal-hal yang disukai dan tidak disukai beserta emosi dan sikap yang sering muncul ketika hal tersebut terjadi. Kemudian dilanjutkan dengan diskusi untuk memahami manfaat selfinsight tersebut.

c. Sesi III:

Peserta fokus pada pembentukan makna dan tujuan hidup melalui selfimagery. Peserta diajak membayangkan hal-hal di masa depan, dan kesiapan mereka berdasarkan pengalaman lalu. Selanjutnya fokus pada pembuatan tujuan dalam long term ataupun short term.

d. Sesi IV:

Fokus pada changing attitude. Sesi ini membahas mengenai tujuan hidup dan cita-cita peserta. Mereka dibantu agar mampu menentukan cita-cita dalam 
gambaran jelas berkaitan dengan potensi diri dan lingkungannya.

e. Sesi V:

Peserta diarahkan untuk mampu mengidentifikasi tujuan hidupnya berdasarkan konsep SMART dan memahami keuntungan dan kerugian yang dapat terjadi di depannya.

f. Sesi VI:

Sesi ini melibatkan kegiatan yang berupaya untuk membangkitkan efikasi diri peserta sehingga mampu terikat pada komitmen untuk mencapai tujuan hidup.

\section{Teknik Analisis Data}

Setelah peneliti memperoleh data tes awal dan tes akhir, peneliti melakukan uji normalitas, uji homogenitas dan uji beda (Seniati et al., 2005). Data yang diperoleh menunjukan kondisi normal, kemudian dilakukan analisis deskriptif dan uji statistik menggunakan teknik paired sample t-test untuk membandingkan skor tes awal dan tes akhir.

\section{HASIL PENELITIAN}

Evaluasi pada aspek penerimaan diri dilakukan dengan memberikan prates dan paskates pada partisipan untuk mengukur penerimaan diri. Sebelum proses pelatihan hari pertama dimulai, remaja diberikan soal tes awal untuk mengukur tingkat penerimaan dirinya, kemudian setelah pelatihan hari kedua selesai, remaja kembali diberi soal yang sama sebagai tes akhir pascapelatihan. Hasil pelatihan dilihat dari hasil uji statistik dan analisis trend skor penerimaan diri remaja sebelum dan setelah pelatihan. Tabel 2 berikut ini merupakan hasil pelatihan:

Tabel 2. Uji Komparasi Penerimaan diri

\begin{tabular}{lcccc}
\hline Hasil Tes & Berata & $\begin{array}{c}\text { Jumlah } \\
\text { Dartisipan }\end{array}$ & $\begin{array}{c}\text { Standar } \\
\text { Deviasi }\end{array}$ & $\begin{array}{c}\text { Standar } \\
\text { Deviasi } \\
\text { Rerata }\end{array}$ \\
\hline Pra Tes & 61.6429 & 14 & 4.58437 & 1.22523 \\
Paska Tes & 65.5714 & 14 & 4.79927 & 1.28266 \\
\hline
\end{tabular}

Pada tabel 2 dapat dilihat bahwa mean skor tes awal sebesar 61.64 yaitu lebih kecil dibandingkan skor mean pada paskates yaitu sebesar 65.57. Kenaikan mean dari data prates ke paskates mengindikasikan bahwa rata-rata skor penerimaan diri peserta lebih besar setelah mengikuti training.

Tabel 3. Uji Beda

\begin{tabular}{|c|c|c|c|c|c|c|c|c|}
\hline \multicolumn{9}{|c|}{ Paired Differences } \\
\hline & \multirow[t]{2}{*}{ Mean } & \multirow[t]{2}{*}{$\begin{array}{c}\text { Std. } \\
\text { Deviation }\end{array}$} & \multirow[t]{2}{*}{$\begin{array}{l}\text { Std. } \\
\text { Error } \\
\text { Mean }\end{array}$} & \multicolumn{2}{|c|}{$\begin{array}{l}95 \% \text { Confidence } \\
\text { Interval of the } \\
\text { Difference }\end{array}$} & \multirow[t]{2}{*}{$\mathbf{t}$} & \multirow[t]{2}{*}{ df } & \multirow[t]{2}{*}{$\begin{array}{l}\text { Sig. (2- } \\
\text { tailed) }\end{array}$} \\
\hline & & & & Upper & Lower & & & \\
\hline Pra Tes & - & 5.18080 & 1.38463 & - & -0.93727 & -2.837 & 13 & 0.014 \\
\hline Paska Tes & 3.92857 & & & 6.91987 & & & & \\
\hline
\end{tabular}

Berdasarkan hasil uji statistik menggunakan teknik paired sample t-test diperoleh nilai signifikansi sebesar $0.014<0.05$ yang berarti terdapat 
perbedaan antara skor prates sebelum training dengan paskates setelah peserta peserta menerima perlakukan dalam mengikuti training.

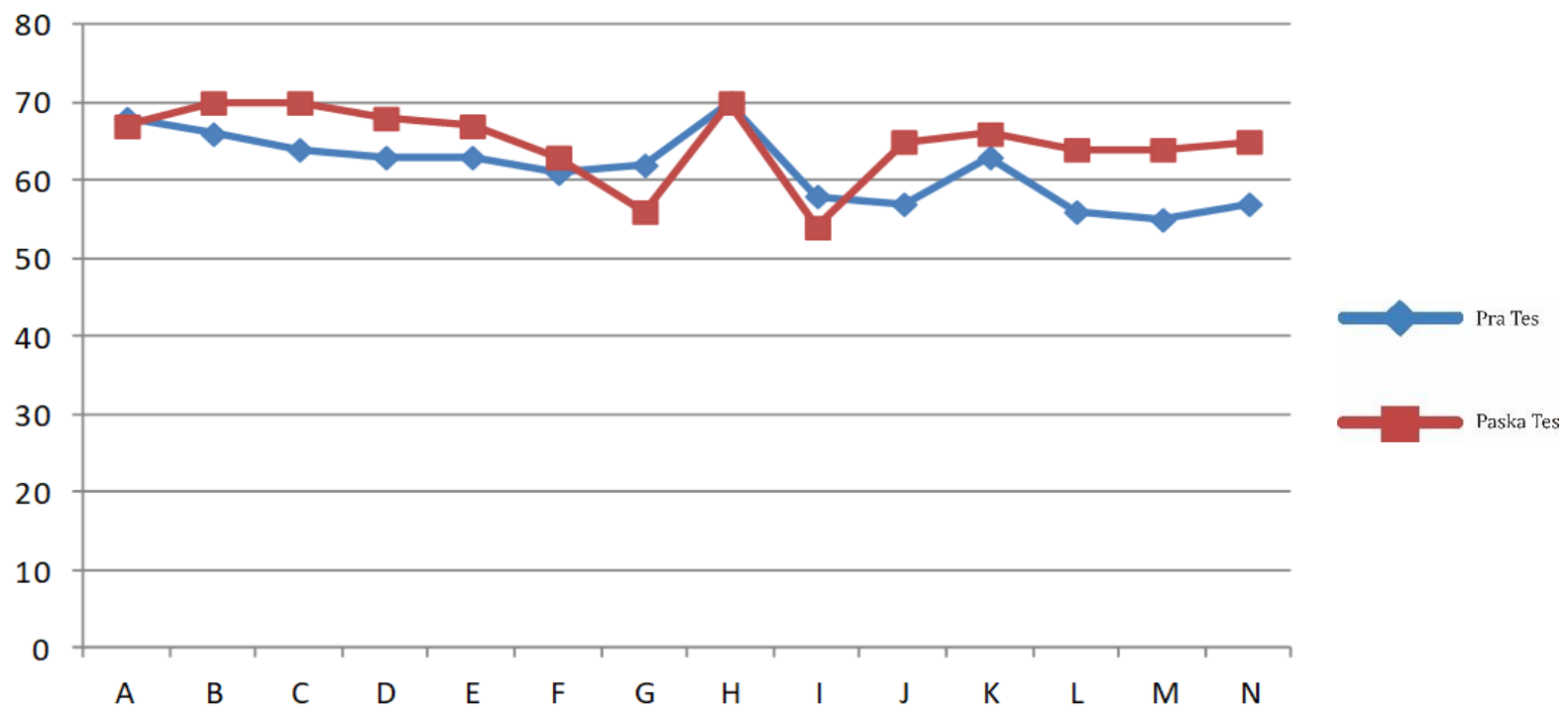

Gambar 2. Grafik Trend skor penerimaan diri remaja

Sebagian besar peserta mengalami peningkatan grafik dari prates ke paskates, peningkatan penerimaan diri mayoritas peserta yang ditunjukkan grafik di atas berpengaruh terhadap signifikansi uji beda. Akan tetapi, pada subjek G dan I terlihat ada penurunan grafik, namun tetap berada di kategori yang sama.

Gambaran perbandingan skor di antara masing-masing peserta dipaparkan dalam tabel 4 di bawah ini:

Tabel 4. Perbandingan Skor Penerimaan Diri

\begin{tabular}{lcccccrc}
\hline No & Peserta & \multicolumn{2}{c}{ Pra-tes } & \multicolumn{2}{c}{ Paska-tes } & \multicolumn{2}{c}{ Keterangan } \\
& & Skor & Kategori & Skor & Kategori & Jarak Skor & Kategori \\
\hline $\mathbf{1}$ & A & 68 & Tinggi & 67 & Tinggi & -1 & Tetap \\
$\mathbf{2}$ & B & 66 & Tinggi & 70 & Tinggi & +4 & Tetap \\
$\mathbf{3}$ & C & 64 & Sedang & 70 & Tinggi & +6 & Naik 1 jeniang \\
$\mathbf{4}$ & D & 63 & Sedang & 68 & Tinggi & +5 & Naik 1 jenjang \\
$\mathbf{5}$ & E & 63 & Sedang & 67 & Tinggi & +4 & Naik 1 jeniang \\
$\mathbf{6}$ & F & 61 & Sedang & 63 & Sedang & +2 & Tetap \\
$\mathbf{7}$ & G & 62 & Sedang & 56 & Sedang & -6 & Tetap \\
$\mathbf{8}$ & H & 70 & Tinggi & 70 & Tinggi & 0 & Tetap \\
$\mathbf{9}$ & I & 58 & Sedang & 54 & Sedang & -4 & Tetap \\
$\mathbf{1 0}$ & J & 57 & Sedang & 65 & Tinggi & +8 & Naik 1 jeniang \\
$\mathbf{1 1}$ & K & 63 & Sedang & 66 & Tinggi & +3 & Naik 1 jenjang \\
$\mathbf{1 2}$ & L & 56 & Sedang & 64 & Sedang & +8 & Tetap \\
$\mathbf{1 3}$ & M & 55 & Sedang & 64 & Sedang & +9 & Naik 1 jeniang \\
$\mathbf{1 4}$ & N & 57 & Sedang & 65 & Tinggi & +8 & Naik 1 jenjang \\
\hline
\end{tabular}

Terlihat bahwa tujuh orang partisipan mengalami kenaikan skor penerimaan diri sebanyak satu jenjang dari awal sebelum mengikuti pelatihan. Sementara tujuh orang partisipan lainnya memiliki skor yang relatif tetap tidak 
mengalami kenaikan maupun penurunan jenjang. Skor penerimaan diri partisipan antara prates dan paskates berada pada rentang kategori sedang hingga tinggi.

Hasil evaluasi pembelajaran (learning) dihimpun dari hasil jawaban peserta pada evaluasi writing task di setiap akhir materi dan hasil observasi perilaku verbal maupun nonverbal yang tercatat oleh fasilitator selama kegiatan pelatihan. Hasil evaluasi learning menggambarkan pemahaman peserta pada masing-masing materi yang trainer sajikan. Tabel 5 berikut ini merupakan pemaparan hasil evaluasi:

Tabel 5. Rangkuman Evaluasi Learning Masing-masing Individu

\begin{tabular}{ccl}
\hline No. & Nama & \multicolumn{1}{c}{ Evaluasi } \\
\hline $\mathbf{1}$ & A & Mampu memahami 5 dari 6 materi yang disajikan dalam pelatihan. \\
$\mathbf{2}$ & B & Mampu memahami 4 dari 6 materi pelatihan. \\
$\mathbf{3}$ & C & Mampu memahami 3 dari 6 materi pelatihan. \\
$\mathbf{4}$ & D & Mampu memahami 5 dari 6 materi pelatihan. \\
$\mathbf{5}$ & E & Mampu memahami 5 dari 6 materi pelatihan. \\
$\mathbf{6}$ & F & Mampu memahami 1 dari 6 materi pelatihan, namun masih kurang \\
& & komprehensif. \\
$\mathbf{7}$ & G & Mampu memahami 1 dari 6 materi pelatihan, namun belum \\
& & sepenuhna dipahami dengan benar. \\
$\mathbf{8}$ & H & Mampu memahami 5 dari 6 materi pelatihan. \\
$\mathbf{9}$ & I & Memahami materi secara sepotong-sepotong. Hampir semua materi \\
& & kurang dipahami \\
$\mathbf{1 0}$ & J & Mampu memahami 5 dari 6 materi pelatihan. \\
$\mathbf{1 1}$ & K & Mampu memahami 4 dari 6 materi pelatihan. \\
\hline
\end{tabular}

Paham atau kurang pahamnya peserta pada materi akan tampak dari hasil jawaban yang dituliskan pada penugasan evaluasi dan didukung oleh data hasil observasi dari trainer dan fasilitator. Soal penugasan pada evaluasi learning sebelumnya sudah dilatihkan terlebih dahulu menggunakan tokoh lain (tokoh dalam film/video atau melalui permainan) dan diiringi dengan diskusi. Setelah tidak ada lagi peserta yang melakukan konfirmasi pada materi, maka diskusi ditutup dan lembar evaluasi dibagikan oleh fasilitator.

Dari data di atas, dapat dilihat bahwa terdapat beberapa materi yang dipahami oleh mayoritas peserta. Materi tersebut yang terkandung pada sesi I terkait pemahaman diri mengggunakan konsep johari window yang meningkatkan self insigh; materi pada sesi II terkait mengenal dan memahami emosi juga berdampak pada aspek meaning of life; serta materi matriks prioritas dan analisa SWOT untuk mencapai tujuan pada sesi $\mathrm{V}$ yang menekankan proses kognitif untuk menyasar aspek changing attitude dan direct activity. Materi tersebut dipahami oleh 10 dari 14 peserta. Materi yang sulit untuk dipahami adalah materi SMART yang membahas aspek tujuan hidup dan kemauan di masa depan. Diasumsikan materi tersebut sulit diterima karena mayoritas remaja masih belum memiliki impian, keinginan dan harapan di masa depan, pada saat pengerjaan peserta juga masih dipandu oleh para mentor.

\section{PEMBAHASAN}

Hasil analisis data menunjukkan adanya perbedaan signifikan skor 
penerimaan diri sebelum dan sesudah dilakukan intervensi. Hal ini menunjukkan bahwa pelatihan yang dilakukan membawa perubahan pada penerimaan diri remaja panti asuhan. Hal ini dikarenakan pelatihan dikemas dengan metode yang menarik dan menyenangkan, namun juga memastikan setiap peserta mampu menangkap intisari dari setiap sesi. Trainer dan para mentor memastikan remaja memahami dan mendapatkan insight dari setiap sesi. Evaluasi ini juga dilakukan dengan cara sharing di dalam kelompok dan depan kelas terkait hal-hal yang mereka dapatkan.

Penelitian serupa belum pernah dilakukan sebelumnya. Penelitian lain yang membahas mengenai pelatihan penerimaan diri lain adalah pelatihan milik Firmansyah et al., (2019) yang menggunakan metode pemaafan. Pelatihan yang dilakukan didasarkan pada empat fase terapi pemaafan milik Enright (Firmansyah et al., 2019), di mana perbedaannya dengan penelitian ini adalah hanya menekankan aspek emosi dan hambatan emosi, sedangkan pada penelitian ini juga menekankan aspek kognitif. Namun, dari hasil penelitian tersebut, terdapat peningkatan penerimaan diri dari subjek, sehingga hasil pelatihan tersebut, jika dibandingkan dengan pelatihan metode ini sama-sama efektif. Kelemahan dari pelatihan yang dilakukan, jika dibandingkan dengan pelatihan ini adalah pelatihan ini tidak memiliki kegiatan yang variatif dan cenderung monoton. Sehingga, apabila merujuk pada subjek remaja panti asuhan, pelatihan metode ini dirasa lebih efektif karena kegiatannya cukup menyenangkan dan mudah dipahami.

Penelitian Wibowo (2015) juga membahas peningkatan penerimaan diri yang dilakukan pada anak jalanan berusia remaja. Metode pada penelitian Wibowo (2015) memiliki beberapa kesamaan dengan penelitian ini, yaitu adanya materi untuk mengenal diri sendiri, psikoedukasi yang merujuk pada nilai-nilai diri, menggali diri dengan menanyakan pada orang lain, dan materi yang dikemas di dalam permainan yang menyenangkan. Hasil penelitian tersebut menunjukkan adanya kenaikan penerimaan diri setelah pelatihan pada remaja jalanan. Dibandingkan dengan hasil penelitian ini, dapat dilihat bahwa materi yang menyasar aspek emosi dan kognitif penting untuk ditekankan dalam keberhasilan penelitian. Selain itu, aktivitas yang menyenangkan dan sederhana merupakan metode yang tepat untuk meningkatkan penerimaan diri remaja. Perbedaan penelitian tersebut dengan pelatihan ini adalah adanya pembahasan terkait langkah-langkah untuk mencapai tujuan agar remaja panti asuhan lebih jelas menentukan tindakan dan dapat mengubah kebiasaan yang menghambat diri.

Trainer melakukan evaluasi pada peserta untuk mengukur pelatihan. Hasil evaluasi level reaksi menunjukkan respon positif dari peserta pada trainer, materi yang disampaikan dalam pelatihan, dan fasilitas yang peserta peroleh. Hanya saja terdapat catatan pada respon peserta mengenai fasilitas, khususnya ruang pelatihan yang dirasa kurang bersih karena karpet alas duduk beraroma tidak sedap (pesing). Selebihnya, peserta merespon sangat baik pada keseluruhan pelatihan.

Pada evaluasi level learning aspek knowledge, sebagian peserta mengalami kemajuan dari tahap latihan hingga evaluasi. Pada awalnya di tahap latihan, peserta masih memerlukan bimbingan. Namun di tahap evaluasi, sebagian peserta telah mampu mengerjakan penugasan secara mandiri. Hanya saja trainer tidak melakukan evaluasi learning berbentuk prates dan paskates yang bersifat teoritik mengenai konsep. Pada aspek attitude, hasil uji statistik menunjukkan bahwa skor penerimaan diri peserta pada prates dan 
paskates signifikan berbeda dan mengalami kenaikan. Sebagian peserta yaitu tujuh remaja mengalami kenaikan penerimaan diri sebanyak satu jenjang dari kategori sedang menjadi tinggi, sementara tujuh orang lainnya memiliki skor penerimaan diri yang relatif tetap. Sebaran skor penerimaan diri peserta saat paskates berada pada rentang sedang hingga tinggi.

Pada evaluasi level behavior, follow-up dilakukan seminggu setelah pelatihan hari kedua. Sumber data evaluasi behavior diperoleh dari orangtua asuh dan peserta sebanyak 8 orang. Mayoritas peserta masih mengingat materi Johari window pada pelatihan hari I, materi matriks prioritas dan SWOT pada pelatihan hari II. Hanya seorang peserta yang tidak mengingat sama sekali materi pelatihan dan belum menerapkan pengetahuan dari pelatihan ke kehidupan keseharian. Peserta lainnya mulai menerapkan materi SWOT untuk menganalisis diri dan lingkungan ketika memperoleh tugas sekolah yang dirasa sulit. Selain itu, peserta juga mulai menerapkan matriks prioritas untuk mengatur aktivitas sehari-hari untuk mengurangi kecenderungan prokrastinasi. Sudut pandang lain yaitu dari orangtua asuh melihat adanya perbedaan pada sebagian remaja setelah mengikuti pelatihan. Mereka kemudian memiliki tujuan hidup yang lebih jelas dan lebih percaya diri mengungkapkan tujuannya sehingga memudahkan pihak panti asuhan untuk menjalankan program mengarahkan remaja mencapai tujuan hidupnya.

Pada hasil uji statistik menunjukkan bahwa skor penerimaan diri partisipan pada prates dan paskates signifikan berbeda dan mengalami kenaikan. Sebagian partisipan yaitu tujuh remaja mengalami peningkatan penerimaan diri sebanyak satu jenjang dari kategori sedang menjadi tinggi, sementara tujuh remaja lainnya memiliki skor penerimaan diri yang relatif tetap.
Sebaran skor penerimaan diri partisipan saat paskates berada pada rentang sedang hingga tinggi. Hal ini juga dipengaruhi oleh kondisi ruangan yang belum siap pada hari kedua. Pada hari ke dua beberapa anak harus membersihkan ruangan tersebut, sehingga mereka mengikuti pelatihan tidak dengan maksimal. Berdasarkan hasil pengamatan dan wawancara, beberapa partisipan yang tidak mengikuti pelatihan hingga akhir juga mempengaruhi konsentrasi partisipan yang ada.

Pada subjek G dan I tampak memiliki skor yang turun dari tes awal ke post test. Hal ini disebabkan oleh kedua subjek selama pelatihan hari kedua cenderung kurang memerhatikan materi dengan serius, mereka cenderung sibuk sendiri, dan terkadang membuat keributan kecil yang mengakibatkan kurangnya pemahaman materi. Ketidakseriusan ini juga ditunjukan pada saat melakukan paskates. Partisipan G dan I memiliki latar belakang masalah yang sulit yaitu merasa diri dibuang oleh orangtuanya yang masih hidup, pada saat memasuki masa-masa remaja awal mereka dipaksa tinggal di panti asuhan, serta cenderung sulit diarahkan. Hal ini juga dipaparkan oleh pihak panti yang sering mengeluhkan $G$ dan I. Kondisi ini sesuai dengan studi literatur yang dilakukan oleh (Raws, 2018) terhadap beberapa penelitian, bahwa anak-anak dengan penolakan akan cenderung tidak mematuhi aturan, kurang bertanggung jawab, dan kondisi ini juga akan memperburuk pengasuhan serta memengaruhi kesejahteraan pengasuh, sehingga akan membentuk pola yang tidak sehat dalam mekanisme pengasuhannya. Mereka yang merasa terbuang juga akan memiliki risiko yang lebih besar terhadap perilaku maladaptif.

Pada evaluasi pelaksanaan, sebagian partisipan mengalami kemajuan dari tahap latihan hingga evaluasi. Pada 
awalnya di sesi satu pelatihan partisipan masih memerlukan bimbingan untuk mengikuti materi, namun di sesi ke dua sebagian partisipan telah mampu mengerjakan penugasan secara mandiri. Akan tetapi, trainer tidak melakukan evaluasi learning berbentuk prates dan paskates yang bersifat teoritik mengenai konsep sehingga tidak tahu bagaimana perkembangan partisipan secara knowledge.

Pada follow-up dilakukan seminggu setelah pelatihan hari kedua. Sumber data evaluasi behavior diperoleh dari orangtua asuh dan partisipan sebanyak 8 orang. Mayoritas partisipan masih mengingat materi pada pelatihan hari I dan pada pelatihan hari II. Hanya seorang partisipan yang tidak mengingat sama sekali materi pelatihan dan belum menerapkan pengetahuan dari pelatihan ke kehidupan keseharian. Partisipan lainnya mulai menerapkan materi untuk menganalisis diri dan lingkungan ketika memperoleh tugas sekolah yang dirasa sulit. Selain itu, partisipan juga mulai menerapkan matriks prioritas untuk mengatur aktivitas sehari- hari untuk mengurangi kecenderungan prokrastinasi. Sudut pandang lain yaitu dari orangtua asuh melihat adanya perbedaan pada diri sebagian remaja setelah mengikuti pelatihan. Mereka memiliki tujuan hidup yang lebih jelas dan lebih percaya diri mengungkapkan tujuannya sehingga memudahkan pihak panti asuhan untuk menjalankan program mengarahkan remaja mencapai tujuan hidupnya. Evaluasi yang dilakukan menunjukan bahwa pelatihan ini memberikan dampak bagi remaja Panti Asuhan $\mathrm{X}$ untuk mengembangkan penerimaan diri yang berguna bagi kesejahteraan mereka.

Trainer menyadari bahwa selama proses pelatihan sejak awal hingga akhir, tidak lepas dari kelemahan dan kelebihan. Kelemahan dan kelebihan pelatihan diuraikan dengan harapan dapat digunakan sebagai cerminan melakukan pelatihan serupa di masa yang akan datang. Pendukung dan penghambat pelatihan ini dijelaskan dalam tabel $6 \mathrm{di}$ bawah ini:

Tabel 6. Pendukung dan Penghambat Pelatihan

\begin{tabular}{|c|c|c|}
\hline & Pendukung & Penghambat \\
\hline Internal & $\begin{array}{l}\text { 1. Persiapan matang dari trainer berupa kesiapan } \\
\text { psikis dan penguasaan materi. } \\
\text { 2. Hubungan antara kedua trainer cukup dekat } \\
\text { sehingga kerjasama mudah terjalin dalam } \\
\text { proses training. } \\
\text { 3. Sebagian trainer telah memiliki pengalaman } \\
\text { memberi pelatihan di panti asuhan. }\end{array}$ & $\begin{array}{l}\text { 1. Kurang antisipasi pada kegiatan } \\
\text { peserta di hari kedua. }\end{array}$ \\
\hline \multirow[t]{3}{*}{ Eksternal } & $\begin{array}{l}\text { 1. Kuantitas dan kualitas fasilitator mampu } \\
\text { membantu kelancaran kegiatan. } \\
\text { 2. Raport yang tejalin baik antara trainer dengan }\end{array}$ & $\begin{array}{l}\text { 1. Keterbatasan waktu yang } \\
\text { diberikan oleh pihak panti } \\
\text { asuhan. }\end{array}$ \\
\hline & $\begin{array}{l}\text { orangtua asuh, dan antara trainer dengan } \\
\text { peserta. } \\
\text { 3. Karateristik peserta yang ramah, mudah diberi } \\
\text { arahan. }\end{array}$ & $\begin{array}{l}\text { 2. Jeda antara hari pertama dan hari } \\
\text { kedua pelatihan cukup jauh } \\
\text { sehingga sebagian peserta } \\
\text { melupakan materi. }\end{array}$ \\
\hline & $\begin{array}{l}\text { 4. Antusiasme peserta pada aktivitas seperti } \\
\text { games dan menonton film sebagai cara lain } \\
\text { memperoleh pengetahuan. }\end{array}$ & $\begin{array}{l}\text { 3. Sebagian peserta mengikuti } \\
\text { Perkemahan Sabtu Minggu dan } \\
\text { beberapa membuat tugas akhir } \\
\text { untuk ujian akhir semester. }\end{array}$ \\
\hline
\end{tabular}




\section{SIMPULAN}

Kesimpulan dari penelitian ini adalah aspek self-insight, meaning of life, changing attitude, self-commitment, directed activities, dan social support yang dilakukan dalam pelatihan ini dapat meningkatkan penerimaan diri remaja panti asuhan Islam $X$ di Surabaya. Aspek yang paling menunjukkan perbedaan dalam penelitian ini adalah aspek self- insight, meaning of life, changing attitude, dan directed activities. Berdasarkan hasil wawancara, pelatihan ini tidak hanya meningkatkan penerimaan diri remaja panti, namun juga mengubah perilaku remaja Panti Asuhan Islam X.

\section{Saran}

Saran yang dapat diberikan kepada pihak panti asuhan adalah perlunya pendampingan yang lebih baik agar semangat dan komitmen remaja panti dapat terus berkembang dan terjaga. Kemudian, perlunya pemberian waktu yang lebih panjang, mengingat kemampuan remaja panti, mereka dapat menyerap setiap sesi dengan baik namun adanya kelelahan karena waktu yang panjang setelah mengikuti sesi yang panjang. Pemberian fasilitas untuk pelatihan lanjutan bagi remaja panti juga dapat dilakukan agar kualitas individu dapat berkembang lebih baik.

Penelitian selanjutnya disarankan untuk lebih mengontrol variabel yang dapat mempengaruhi hasil eksperimen yang ada. Selanjutnya juga dapat mengembangkan penelitian ini dengan meneliti aspek mana yang paling berpengaruh pada peningkatan penerimaan diri dan membuat pelatihan yang disesuaikan hasil tersebut.

Saran bagi pemerintahan dan lembaga perlindungan anak, diharapkan dapat memberikan pelatihan-pelatihan dan kurikulum yang wajib dimiliki setiap panti terkait peningkatan penerimaan diri atau pelatihan sejenis untuk meningkatkan kualitas diri remaja panti asuhan. Pada saat kualitas individu yang tinggal di dalam panti meningkat, kesenjangan serta citra bangsa akan membaik.

\section{DAFTAR PUST AKA}

Atwater, E. (1983). Psychology of Adjustment (2nd Editio). Prentice-Hall Inc.

https://www.amazon.com/Psychology -adjustment-Personal-growthchanging/dp/013734855X

Bahari, H. (2013). Permainan-permainan perangsang karakter positif anak. Diva Press.

Bastaman, H. . (2007). Logoterapi : psikologi untuk menemukan makna hidup dan meraih hidup bermakna. Raja Grafindo Persada.

Carpenter, K. (2014). Using Orphanage Spaces to Combat Envy and Stigma.
Children, Youth and Environments, 24(1), 124-137.

https://doi.org/10.7721/chilyoutenvi. 24.1.0124

Feist, J., \& Feist, G. (2009). Theories of personality (7th ed.). McGraw-Hill Bokk Co.

Firmansyah, O. B. M., Bashori, K., \& Hayati, E. N. (2019). Pengaruh Terapi Pemaafan Dengan Dzikir Untuk Meningkatkan Penerimaan Diri Pada Orang Dengan HIV/AIDS (ODHA). Psikis : Jurnal Psikologi Islami, 5(1), 1323. https://doi.org/10.19109/Psikis.v5i1. 2036 
Hermenau, K., Eggert, I., Landolt, M. A., \& Hecker, T. (2015). Neglect and perceived stigmatization impact psychological distress of orphans in Tanzania. European Journal of Psychotraumatology, 6(1), 1-9. https://doi.org/10.3402/ejpt.v6.2861 7

Hjelle, L. A., \& Ziegler, D. J. (1981). Personality theories: basic assumptions, research and applications (Third). McGraw-Hill Bokk Co.

Khan, T. F., \& Jahan, M. (2015).

Psychological Well-Being and Achievement Motivation Among Orphan and Non-Orphan Adolescents of Kashmir. Indian Journal of Health and Wellbeing; Vol 6, No 8 (2015), 6(8), 769-773. http://www.ischolar.in/index.php/ijhw/article/vie $\mathrm{w} / 147373$

Kuyumcu, B., \& Rohner, R. P. (2018). The relation between remembered parental acceptance in childhood and self-acceptance among young Turkish adults. International Journal of Psychology, 53(2), 126-132. https://doi.org/10.1002/ijop.12277

Mertens, D. M. (2014). Research and evaluation in education and psychology, 4th Edition. Thousand Oaks: Sage Publication Inc. (4th ed.). SAGE Publications Inc. https://www.amazon.com/Research-
Evaluation-Education-PsychologyQuantitative/dp/1452240272

Moekijat. (1981). Latihan dan pengembangan pegawai. penerbit alumni.

Newman, B. M., \& Newman, P. R. (2012). Development through life: A psychosocial approach (13th ed.). Cengage Learning.

Papalia, D., Olds, S., \& Feldman, R. (2008). Human Development (11th ed.). McGraw-Hill Bokk Co.

Raws, P. (2018). A review of research on adolescent neglect focusing on identification, assessment and intervention. Thinking about adolescent neglect.

Seniati, L., Yulianto, A., \& Setiadi, B. N. (2005). Psikologi eksperimen (S. Darwin (ed.)). Indeks.

Wibowo, K. P. (2015). Efektivitas Pelatihan Penerimaan Diri Pada Anak Jalanan. Jurnal Psikologi, 8(2), 139-145. https://ejournal.gunadarma.ac.id/inde x.php/psiko/article/view/1646

Wiraswati. (2016). "Mamahami Kebutuhan anak Panti Asuhan." Hasil Wawancara Pribadi:11 September 2016, Panti Asuhan. 